\title{
Polyethylene/Aluminum/Polyethylene Composite Pipe for Fuel Gas Application
}

\author{
Baiqian Li, Mingxuan Li, Lixian Zheng, Lei Wang and Guozhi Xu \\ Rifeng Group Co. Ltd., Foshan 528000, Guangdong, China
}

\begin{abstract}
Polyethylene/aluminum/polyethylene (PAP) composite pipe has the advantages of corrosion resistance, limited joints and convenient installation. We started to use the PAP pipe in fuel gas conveyance 21 years ago. It has excellent performance in indoor gas application. Later, a unique method was designed to apply the PAP pipe in outdoor gas conveyance with the appearance of outdoor gas meter setting, which involves the addition of UPVC casing pipe as a protection technique to prevent the aging of PAP pipe. The method allows the PAP pipe to climb on the outer wall of building and get into user's home directly after the connection with outdoor gas meter without any joints in the middle. Since 1996, the number of users has increased gradually and it achieves millions level globally today, including Europe, Asia, Oceania, South America and Africa. There were no quality and performance issues of using the PAP pipe in fuel gas conveyance indoor and outdoor in the past 20 years. In this paper, we put our effort on studying the effects of environmental temperature, sealing reliability, resistance to pipe pull-out, thermal compensation, and rat biting on PAP pipe and solve these problems.
\end{abstract}

Key words: Composite pipe, gas application, anti-rodent.

\section{Introduction}

Aluminum-plastic composite pipe (PAP) is a kind of pipe with a five-layer structure. The inner layer and the outer layer are made of polyethylene, the middle layer is welded with aluminum tube, and the aluminum layer is integrated with the inner and outer plastic layers through polyglue. Compared with the traditional galvanized steel pipe, PAP pipe combines the advantages of plastic and metal. As a composite pipe, it has the advantages of corrosion resistance, long life, bending without rebound, easy installation, so in early 90s of the last century, PAP pipe began to replace galvanized steel pipes for the construction of plumping system pipes. In 1996, Rifeng first used PAP for indoor gas pipes to replace traditional galvanized steel pipes. In order to popularize this technique in China, we had participated in the development of relevant standard specification, such as national standard (GB50028-2006), industry

Corresponding author: Baiqian Li, Ph.D., research field: plastic pipes. standard (CJJ94-2009) [1] and association standard (CECS264-2009) [2]. After accumulating sufficient application experience, PAP pipe was included in the GB 50028 "code for design of city gas engineering". Rifeng Gas PAP pipe currently has millions level households in China and is exported to Europe, Asia, Oceania, South America and Africa.

The main advantages of PAP for indoor gas are:

(1) Zero gas transmission rate and high safety factor Due to its unique five-layer structure (showed in Fig. 1), the PAP pipe has zero gas transmission. According to the requirements of GB/T 18997.1 "Polyethylene/Aluminum/Polyethylene (PE-AL-PE) Composite Pressure Pipe-Part 1: PE/AL/PE pipe overlap-welded by aluminum pipe", the hydrostatic strength of PAP at $60{ }^{\circ} \mathrm{C}$ is $2.72 \mathrm{MPa}$, the blasting strength reaches 7.0 MPa [3]. Indoor gas pressure is less than $10 \mathrm{kPa}$, PAP pipe used in gas has a very high safety factor. Fig. 2 shows an indoor application of PAP pipes.

(2) Welding with 0.6 MPa compressed air

PAP pipe has two types: overlap-welding and butt welding according to the welding method of the 
aluminum pipe. Overlap-welded PAP pipe, aluminum ribbons are overlap-welded and form a tube, then pass through the co-extrusion die of extruder, and the co-extrusion die simultaneously extrudes polyglue and polyethylene in the inner layer of the aluminum tube. Since the plastic is just extruded from the die, compressed air is needed to make the plastic contact closely to the aluminum tube's inner wall. In this process, we added the compressed air pressure to 0.6 MPa. Once there is a fake weld or missing weld, the overlap will burst open, the compressed air in the tube can play an online detection role. Therefore, the application of overlap welding PAP pipe in gas is safer than butt welded one.

(3) Limited joints, easy installation

The connection of the PAP pipe adopts the press-type connection, easy operation and reliable. It is easy to bend and does not bounce back. There are limited joints and the probability of leakage is low.

With the increase of fuel gas users in China, the application of PAP pipe in fuel gas has a professional development. But a number of companies encounter difficulties in installing gas meter in users' house as well as charging. Some customers try to solve this problem by setting all the gas meters altogether outdoor and using the UPVC cased PAP pipe, as demonstrated in Fig. 3.

However, when PAP pipes are used outdoors, new problems such as environmental temperature, sealing reliability, resistance to pipe pull-out, thermal compensation, and rat biting should be considered and resolved.

\section{Experimental Results}

\subsection{Environmental Temperature}

If PAP pipes are used outdoors, effective measures should be conducted to prevent UV damage, heat and external damage, of which the environmental temperature is a major problem.

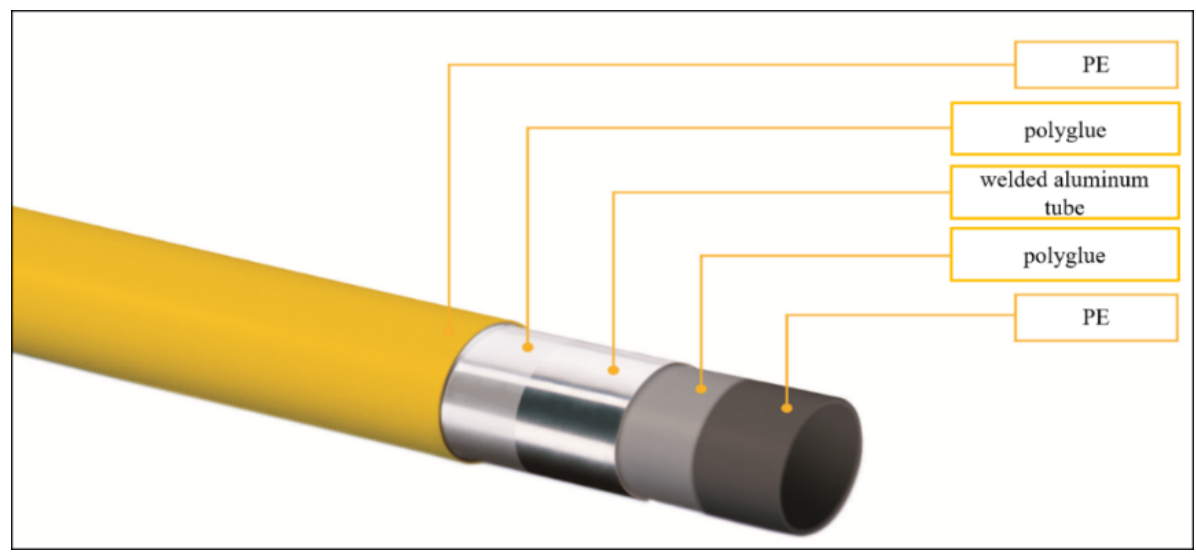

Fig. 1 Schematic diagram of five-layer structure of PAP for fuel gas application.

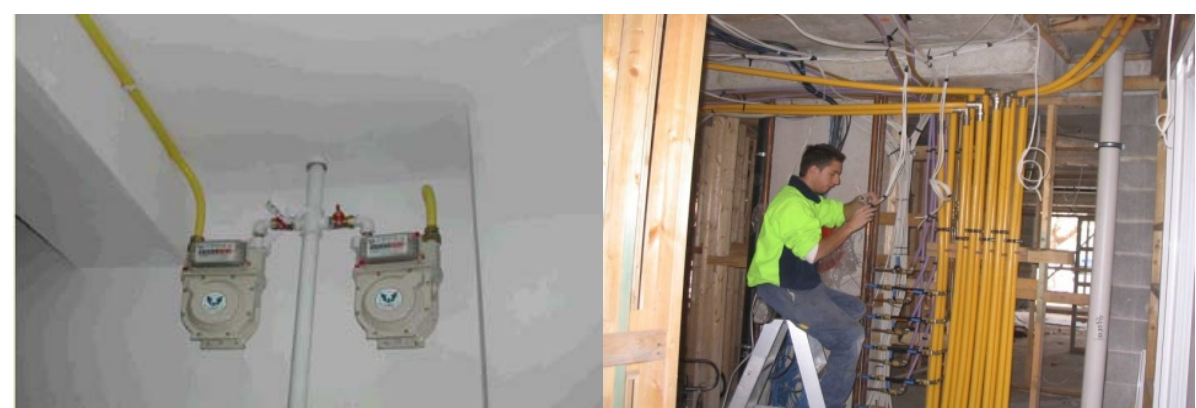

Fig. 2 PAP pipes indoor applications. 

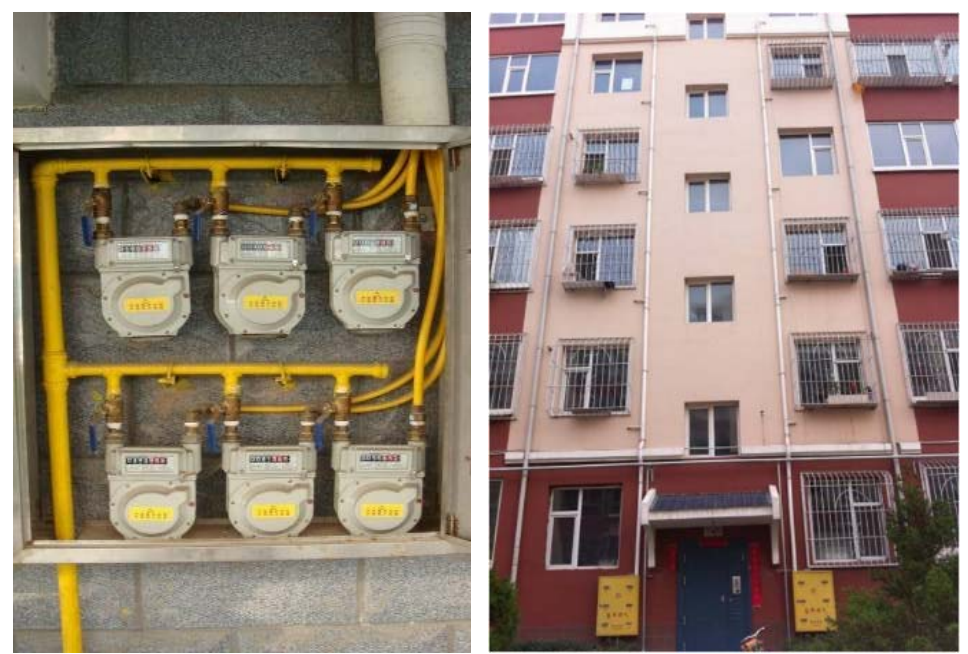

Fig. 3 Outdoor gas meters (left) and UPVC casing PAP pipes (right).

In order to study the changes in environmental temperature in outdoor installation casings, relevant monitoring tests were conducted in the cities of southern and northern China. According to the characteristics of seasonal changes and daily temperature changes, Zhengzhou Gas Company also selected four locations in the northeast, southeast, and northwest directions according to the location of installation of UPVC casing on the PAP pipe outdoor gas meters. Altogether 16 points were considered as a pilot. These pilots were distributed in four districts in the eastern and western regions of Zhengzhou respectively. According to the highest historical temperature in Zhengzhou $\left(43{ }^{\circ} \mathrm{C}\right.$ in 1966) and the lowest temperature (the lowest temperature in 1990 was $-17.9{ }^{\circ} \mathrm{C}$ ), electron thermometer with a range of $-50{ }^{\circ} \mathrm{C}$ to $+250{ }^{\circ} \mathrm{C}$ and a minimum reading of $0.1{ }^{\circ} \mathrm{C}$ were selected. Zhengzhou gas temperature measuring staffs respectively insert the thermometer into the small hole preset in the UPVC casing at the pilot point at 7 o'clock in the morning and 14 o'clock in the afternoon to test the temperature in the casing and record the data. See Tables 1 and 2 for details.

After testing the temperatures in the outdoor UPVC casing in the 16 test points from the 4th June 2007 to the 30th March 2008, 10 months in the coldest and hottest season of the year, the temperature data were collected (shows in Table. 3) and compared with the temperature on the day. The temperature range tested during the test period was -7.1 to $40.6{ }^{\circ} \mathrm{C}$. The maximum temperature of this test is less than $60^{\circ} \mathrm{C}$, and it satisfies the conditions of use specified in standards.

In the southwest of China, spot tests were done by Chongqing Gas Company in August 2007. See Table 4 for details.

The maximum temperature in the pipe is $41.0^{\circ} \mathrm{C}$, which meets the requirement that the environmental temperature should not exceed $60{ }^{\circ} \mathrm{C}$ installed in gas PAP pipe at home and abroad.

\subsection{Connection Seal Reliability}

The connection mode of the PAP pipe in the gas is mainly the press type [4], and the press type connection (demonstrated in Fig. 4) is as follows:

The connection between the compression joint and the fuel gas PAP pipe [5] is realized in this way: the stainless-steel sleeve placed on the outer layer of the PAP pipe is forced to shrink and deform through a special clamping tool, thus the plastic layer on the inner wall of the pipe to contract and snap into the zigzag ring groove on the outer surface of the joint. Since the outer diameter of the two rubber seal O-rings is larger than the outer diameter of the core, the height of the protrusion is about $25 \%$ of the diameter of the seal ring. Therefore, after the inner layer 
Table 1 Standards for gas PAP pipe.

\begin{tabular}{|c|c|c|c|}
\hline No. & Name & Standard number & Application conditions \\
\hline 1 & $\begin{array}{l}\text { Code for Design of City Gas } \\
\text { Engineering }\end{array}$ & GB 50028-2006 & $\begin{array}{l}\text { With mechanical damage prevention, UV damage and heat protection, } \\
\text { environmental temperature should not exceed } 60^{\circ} \mathrm{C} \text {, working pressure } \\
\text { should be less than } 10 \mathrm{kPa} \text {; installed after the metering device (gas meter) } \\
\text { [6]. }\end{array}$ \\
\hline 2 & Australia Gas Installation & AS 5601-2004 & $\begin{array}{l}\text { (a) aluminum plastic composite pipe should not be directly connected to } \\
\text { the burning appliance. } \\
\text { (b) PE/AL/PE pipes should not exceed } 60^{\circ} \mathrm{C} \text { and PEX/AL/PEX (PEX } \\
\text { cross-linked polyethylene) should not exceed } 80^{\circ} \mathrm{C} \text {. } \\
\text { (c) The working pressure should not exceed } 70 \mathrm{kPa} \text {. }\end{array}$ \\
\hline 3 & $\begin{array}{l}\text { European "Construction Gas } \\
\text { Transmission" ( } \mathrm{P} \leq 5 \text { bax })\end{array}$ & EN1775-1998 & $\begin{array}{l}\text { When the polyethylene pipe is installed above the ground, the } \\
\text { polyethylene pipe must be protected against mechanical damage, } \\
\text { ultraviolet (UV) damage and heat protection. }\end{array}$ \\
\hline 4 & $\begin{array}{l}\text { United States "Gas and } \\
\text { Distribution Pipeline System" }\end{array}$ & ASME B31.8-1995 & $\begin{array}{l}\text { (a) Plug into a steel pipe that is resistant to atmospheric corrosion, } \\
\text { deterioration (such as high temperature degradation), and external } \\
\text { damage. } \\
\text { (b) The ground part of the branch line is completely sheathed in a duct or } \\
\text { sleeve with sufficient strength to prevent external damage or to degrade } \\
\text { the quality. } \\
\text { (c) Plastic branch lines should not be subjected to external loads imposed } \\
\text { by gas meters or other connecting lines. }\end{array}$ \\
\hline 5 & $\begin{array}{l}\text { Plastic Pipe System: } \\
\text { Specification for Indoor } \\
\text { Systems (P } \leq 5 \text { bar) }\end{array}$ & ISO 17484-1:2006 & $\begin{array}{l}-20 \sim 60{ }^{\circ} \mathrm{C}, T_{0}=5 \text { bar, resin performance to maintain } 50 \text { years of design } \\
\text { service life. }\end{array}$ \\
\hline
\end{tabular}

of the PAP pipe shrinks, the two O-rings will always be compressed, providing long-lasting sealing performance.

The coefficient of linear expansion of plastic is ten times larger than metal. Therefore, when the cold and heat are alternated, the amount of expansion (shrinkage) is different, and can the seal be reliable? When the temperature of the fluid increases, the amount of plastic expansion is greater than the amount of metal expansion and no gap occurs. When the temperature of the fluid decreases, the amount of shrinkage of the plastic is greater than the amount of metal shrinkage, and a gap will occur in the sealing surface.

The calculation of the maximum gap: we consider the extreme application temperature of gas as $-20 \sim 60{ }^{\circ} \mathrm{C}$, extreme temperature difference as $\Delta T_{\max }=$ $80{ }^{\circ} \mathrm{C}$.

Plastic layer shrinkage $=$ inner plastic thickness $\times$ $\alpha_{\mathrm{PE}} \times \Delta T_{\max }$

Copper core body shrinkage $=$ copper core thickness $\times \alpha_{\mathrm{Cu}} \times \Delta T_{\max }$

Maximum gap $=$ plastic layer shrinkage - copper core shrinkage
Taking 1620 as an example, the maximum gap width is $0.0096-0.0025=0.0071 \mathrm{~mm}$, which is far less than the $0.35 \mathrm{~mm}$ protrusion height of the O-ring (equivalent to $2 \%$ of it). The calculated values of the maximum clearance amount of the remaining specifications and the protruding height of the O-ring are shown in Table 5.

According to our previous discussion, the main parameter that determines the role of the O-ring seal is the compression of the seal ring. From the calculation results in Table 5, the maximum clearance value of all specifications under extreme temperature difference is much smaller than the O-ring protrusion height. Therefore, the compression of the O-ring is hardly affected, and the sealing effect is not affected.

\subsection{Load-Bearing of PAP Pipe}

The PAP pipe is laid along the outer wall and protected by a PVC casing. Because the pipe bracket can not be installed, the weight bearing capacity of PAP pipe should be calculated.

When using 1620 PAP pipe, the weight of the pipe is calculated as follows: 
Table 2 Maximum temperature statistics $\left({ }^{\circ} \mathrm{C}\right)$ during the test period of each test point.

\begin{tabular}{|c|c|c|c|c|c|c|c|c|c|c|c|c|c|c|c|c|c|}
\hline \multirow{3}{*}{ Month } & \multirow{3}{*}{ Temperature } & \multicolumn{16}{|c|}{ Test point } \\
\hline & & $1 \#$ & $2 \#$ & $3 \#$ & $4 \#$ & $5 \#$ & $6 \#$ & $7 \#$ & $8 \#$ & $9 \#$ & $10 \#$ & $11 \#$ & $12 \#$ & $13 \#$ & $14 \#$ & $15 \#$ & $16 \#$ \\
\hline & & East & West & South & North & East & West & South & North & East & West & South & North & East & West & South & North \\
\hline $\begin{array}{l}2007 \\
\text { June }\end{array}$ & 38 & 36.5 & 37.1 & 40.6 & 36.1 & 35.8 & 36.8 & 35.2 & 35.2 & 37.5 & 38 & 37.8 & 37.5 & 38.4 & 38.1 & 37.9 & 37.5 \\
\hline July & 35 & 36.9 & 36.8 & 39.3 & 36.9 & 35.3 & 37.6 & 34.7 & 35.2 & 37.8 & 37.5 & 37.8 & 37.7 & 37.6 & 37.9 & 37.5 & 37.8 \\
\hline August & 35 & 38.1 & 38.1 & 39.8 & 38.1 & 35.3 & 36.6 & 35.8 & 35.5 & 37.8 & 37.6 & 37.5 & 37.1 & 37.8 & 37.6 & 37.4 & 37.2 \\
\hline September & 32 & 35.2 & 35.3 & 36.8 & 32.2 & 29.8 & 30.6 & 30.2 & 30.6 & 32.5 & 32.2 & 32.6 & 32 & 32.7 & 32.5 & 32.7 & 32.4 \\
\hline October & 27 & 25.9 & 25.8 & 26.7 & 25.9 & 24.2 & 24.6 & 24.5 & 23.8 & 26.7 & 26.9 & 26.4 & 26 & 26.4 & 26.8 & 26.9 & 26.4 \\
\hline November & 22 & 22.4 & 22.5 & 23.2 & 22.4 & 21 & 21.2 & 20.4 & 21.2 & 18.7 & 18.8 & 18.6 & 18.7 & 18.5 & 18.5 & 18.7 & 18.9 \\
\hline December & 13 & 9.8 & 9.8 & 10.2 & 9.8 & 14.8 & 14.6 & 15.2 & 14.8 & 13.2 & 13.8 & 13.6 & 13.1 & 13.4 & 13.3 & 13.3 & 13.7 \\
\hline $\begin{array}{l}2008 \\
\text { January }\end{array}$ & 13 & 11.6 & 11.8 & 12.3 & 11.8 & 14.1 & 14 & 14.5 & 14 & 12.4 & 12.1 & 13.8 & 12.2 & 12.7 & 16.5 & 19.7 & 12.5 \\
\hline February & 19 & 18.6 & 18.7 & 19.2 & 18.9 & 16.4 & 16.8 & 17.6 & 16.6 & 17 & 16.8 & 17.1 & 16.7 & 17.1 & 16.8 & 17.2 & 16.9 \\
\hline March & 26 & 23.2 & 23.3 & 26.6 & 27.1 & 25.2 & 26.8 & 27.6 & 24.6 & 25.6 & 25.7 & 25.6 & 26 & 25.1 & 26.6 & 26.4 & 25.3 \\
\hline $\begin{array}{l}\text { Highest } \\
\text { temperature }\end{array}$ & 38 & 38.1 & 38.1 & 40.6 & 38.1 & 35.8 & 37.6 & 35.8 & 35.5 & 37.8 & 38 & 37.8 & 37.7 & 38.4 & 38.1 & 37.9 & 37.8 \\
\hline
\end{tabular}

Table 3 Minimum temperature statistics $\left({ }^{\circ} \mathrm{C}\right)$ during the test period of each test point.

\begin{tabular}{|c|c|c|c|c|c|c|c|c|c|c|c|c|c|c|c|c|c|}
\hline \multirow{3}{*}{ Month } & \multirow{3}{*}{ Temperature } & \multicolumn{16}{|c|}{ Test point } \\
\hline & & $1 \#$ & $2 \#$ & $3 \#$ & $4 \#$ & $5 \#$ & $6 \#$ & $7 \#$ & $8 \#$ & $9 \#$ & $10 \#$ & $11 \#$ & $12 \#$ & $13 \#$ & $14 \#$ & $15 \#$ & $16 \#$ \\
\hline & & East & West & South & North & East & West & South & North & East & West & South & North & East & West & South & North \\
\hline $\begin{array}{l}2007 \\
\text { June }\end{array}$ & 18 & 22.7 & 22.5 & 22.3 & 22.5 & 22.7 & 22.9 & 23.5 & 22.8 & 21.3 & 21.5 & 21.4 & 22.3 & 23.3 & 24.3 & 21.5 & 23.4 \\
\hline July & 19 & 22.3 & 22.3 & 22.4 & 22.5 & 20.3 & 21.2 & 21.6 & 20.4 & 21.3 & 21.4 & 21.6 & 21.3 & 21.3 & 21.5 & 21.5 & 21.5 \\
\hline August & 18 & 19.5 & 19.4 & 19.6 & 19.6 & 18.4 & 18 & 18.2 & 18.8 & 18.5 & 18.7 & 18.4 & 18.2 & 18.6 & 18.8 & 18.5 & 18.2 \\
\hline September & 13 & 18.9 & 18.5 & 19.5 & 20.4 & 13.2 & 13.4 & 13.6 & 13 & 15 & 15.5 & 15.3 & 15.1 & 15.1 & 15.1 & 15.2 & 15.4 \\
\hline October & 5 & 7.6 & 6.7 & 6.9 & 6.7 & 12.6 & 12.2 & 12.2 & 12.1 & 7.4 & 7.3 & 7.4 & 7.2 & 7.3 & 7.3 & 7.7 & 7.4 \\
\hline November & 0 & 2.8 & 2.5 & 2.5 & 2.6 & 6.6 & 7 & 7.2 & 6.6 & 1.8 & 1.7 & 1.5 & 1 & 1.2 & 1.9 & 1 & 1.6 \\
\hline December & -4 & 0.4 & 0.8 & 0.6 & 0.9 & 1.1 & 1.8 & 1.6 & 1.2 & -4.2 & -4.9 & -4.4 & -4.1 & -4.1 & -4.8 & -4.4 & -4.7 \\
\hline $\begin{array}{l}2008 \\
\text { January }\end{array}$ & -7 & -7.1 & -2.6 & -2.7 & -2.7 & -1.8 & -1.6 & -1.8 & -1.6 & -3 & -3.4 & -3.1 & -3.2 & -4 & -3.2 & -3.6 & -3.8 \\
\hline February & -6 & -2.3 & -2.1 & -1.9 & -1.8 & 0.4 & 0.3 & 0.8 & 0.2 & -2.2 & -2 & -1.9 & -2.8 & -2.8 & -2.6 & -2 & -3.5 \\
\hline March & 1 & 6.3 & 5.4 & 5.4 & 5.5 & 9.2 & 9.2 & 9.6 & 8.3 & 1.7 & 2 & 1.8 & 1.9 & 2.2 & 2 & 2.6 & 2.4 \\
\hline $\begin{array}{l}\text { Highest } \\
\text { temperature }\end{array}$ & -7 & -7.1 & -2.6 & -2.7 & -2.7 & -1.8 & -1.6 & -1.8 & -1.6 & -4.2 & -4.9 & -4.4 & -4.1 & -4.1 & -4.8 & -4.4 & -4.7 \\
\hline
\end{tabular}


Table 4 Temperature Monitoring of UPVC casings with PAP pipes with outdoor-installed gas meter in Chongqing $\left({ }^{\circ} \mathrm{C}\right)$.

\begin{tabular}{|c|c|c|c|c|c|c|c|c|c|c|c|c|c|}
\hline \multirow[b]{2}{*}{ Date } & \multirow[b]{2}{*}{ Time } & \multicolumn{3}{|c|}{ Weather conditions } & \multirow{2}{*}{$\begin{array}{l}\text { Temperature } \\
\text { on UPVC } \\
\text { casing's } \\
\text { outside } \\
\text { surface }\end{array}$} & \multirow[b]{2}{*}{$\begin{array}{l}\text { Temperature } \\
\text { inside UPVC } \\
\text { casings }\end{array}$} & \multirow{2}{*}{$\begin{array}{l}\text { Outer surface } \\
\text { temperature } \\
\text { of the PAP } \\
\text { pipe }\end{array}$} & \multirow{2}{*}{$\begin{array}{l}\text { Outer surface } \\
\text { temperature } \\
\text { of fiberglass } \\
\text { case }\end{array}$} & \multirow{2}{*}{$\begin{array}{l}\text { Environmental } \\
\text { temperature in } \\
\text { the meter case }\end{array}$} & \multirow{2}{*}{$\begin{array}{l}\text { Relative } \\
\text { humidity } \\
\text { in meter } \\
\text { case }\end{array}$} & \multirow{2}{*}{$\begin{array}{l}\text { Outer } \\
\text { surface } \\
\text { temperature } \\
\text { of gas meter }\end{array}$} & \multirow{2}{*}{$\begin{array}{l}\text { Outer surface } \\
\text { temperature } \\
\text { of fuel gas } \\
\text { pipe }\end{array}$} & \multirow{2}{*}{$\begin{array}{l}\text { Angle of } \\
\text { sunlight } \\
\text { exposure }\end{array}$} \\
\hline & & Temperature & Humidity & $\begin{array}{l}\text { Surface } \\
\text { temperature }\end{array}$ & & & & & & & & & \\
\hline 2007.8 .21 & $11: 50$ & $36.5^{\circ} \mathrm{C}$ & $42 \%$ & $46.8^{\circ} \mathrm{C}$ & $39.7^{\circ} \mathrm{C}$ & $36.7^{\circ} \mathrm{C}$ & $36.8^{\circ} \mathrm{C}$ & $52.5^{\circ} \mathrm{C}$ & $40.2^{\circ} \mathrm{C}$ & $45 \%$ & $41.2^{\circ} \mathrm{C}$ & - & $90^{\circ}$ \\
\hline 2007.8 .22 & $13: 00$ & $39.2^{\circ} \mathrm{C}$ & $50 \%$ & $48.0^{\circ} \mathrm{C}$ & $43.0^{\circ} \mathrm{C}$ & $38.8^{\circ} \mathrm{C}$ & $39.2^{\circ} \mathrm{C}$ & $52.3^{\circ} \mathrm{C}$ & $41.7^{\circ} \mathrm{C}$ & $55 \%$ & $41.8^{\circ} \mathrm{C}$ & $45.7^{\circ} \mathrm{C}$ & $90^{\circ}$ \\
\hline 2007.8 .23 & $13: 00$ & $37.0^{\circ} \mathrm{C}$ & $48 \%$ & $47.2^{\circ} \mathrm{C}$ & $41.2^{\circ} \mathrm{C}$ & $37.5^{\circ} \mathrm{C}$ & $38.0^{\circ} \mathrm{C}$ & $51.9^{\circ} \mathrm{C}$ & $40.7^{\circ} \mathrm{C}$ & $49 \%$ & $41.5^{\circ} \mathrm{C}$ & $45.2^{\circ} \mathrm{C}$ & $90^{\circ}$ \\
\hline 2007.8 .27 & $12: 30$ & $39.7^{\circ} \mathrm{C}$ & $44 \%$ & $47.8^{\circ} \mathrm{C}$ & $42.5^{\circ} \mathrm{C}$ & $39.5^{\circ} \mathrm{C}$ & $38.8^{\circ} \mathrm{C}$ & $57.5^{\circ} \mathrm{C}$ & $41.2^{\circ} \mathrm{C}$ & $45 \%$ & $42.2^{\circ} \mathrm{C}$ & $47.5^{\circ} \mathrm{C}$ & $90^{\circ}$ \\
\hline 2007.8 .28 & $13: 30$ & $41.0^{\circ} \mathrm{C}$ & $41 \%$ & $56.8^{\circ} \mathrm{C}$ & $45.3^{\circ} \mathrm{C}$ & $40.1^{\circ} \mathrm{C}$ & $39.5^{\circ} \mathrm{C}$ & $61.5^{\circ} \mathrm{C}$ & $41.5^{\circ} \mathrm{C}$ & $42 \%$ & $43.8^{\circ} \mathrm{C}$ & $48.6^{\circ} \mathrm{C}$ & $90^{\circ}$ \\
\hline 2007.8 .29 & $12: 40$ & $40.8^{\circ} \mathrm{C}$ & $42 \%$ & $50.1^{\circ} \mathrm{C}$ & $45.0^{\circ} \mathrm{C}$ & $40.0^{\circ} \mathrm{C}$ & $39.2^{\circ} \mathrm{C}$ & $59.5^{\circ} \mathrm{C}$ & $41.2^{\circ} \mathrm{C}$ & $43 \%$ & $42.5^{\circ} \mathrm{C}$ & $47.5^{\circ} \mathrm{C}$ & $90^{\circ}$ \\
\hline 2007.8 .30 & $13: 10$ & $40.7^{\circ} \mathrm{C}$ & $45 \%$ & $50.7^{\circ} \mathrm{C}$ & $45.4^{\circ} \mathrm{C}$ & $41.0^{\circ} \mathrm{C}$ & $40.5^{\circ} \mathrm{C}$ & $62.5^{\circ} \mathrm{C}$ & $43.0^{\circ} \mathrm{C}$ & $45 \%$ & $45.7^{\circ} \mathrm{C}$ & $48.1^{\circ} \mathrm{C}$ & $90^{\circ}$ \\
\hline
\end{tabular}

Table 5 Maximum clearances between different specifications of PAP pipe and fittings at the limit temperature difference of $80{ }^{\circ} \mathrm{C}$.

\begin{tabular}{llllll}
\hline Pipe specifications & $\begin{array}{l}\text { Inner wall thickness } \\
(\mathrm{mm})\end{array}$ & $\begin{array}{l}\text { Pipe body thickness } \\
(\mathrm{mm})\end{array}$ & $\begin{array}{l}\text { Inner plastic shrinkage } \\
(\mathrm{mm})\end{array}$ & $\begin{array}{l}\text { Fitting wall thickness } \\
\text { shrinkage }(\mathrm{mm})\end{array}$ & $\begin{array}{l}\text { Sealing surface } \\
\text { maximum clearance } \\
(\mathrm{mm})\end{array}$ \\
\hline 1014 & 0.8 & 1.85 & 0.0096 & $\begin{array}{l}\text { Seal protruding height } \\
(\mathrm{mm})\end{array}$ \\
1216 & 0.9 & 1.85 & 0.0108 & 0.0024 & 0.0072 \\
1418 & 0.9 & 1.95 & 0.0108 & 0.0024 & 0.0084 \\
1620 & 0.8 & 1.95 & 0.0096 & 0.35 \\
2025 & 1.1 & 2.5 & 0.0132 & 0.0025 & 0.0025 \\
2632 & 1.2 & 2.65 & 0.0144 & 0.0033 & 0.35 \\
\end{tabular}

Linear expansion coefficient of PE: $\alpha_{\mathrm{PE}}=1.5 \times 10^{-4} \mathrm{~m} /\left(\mathrm{m}^{\circ}{ }^{\circ} \mathrm{C}\right)$.

Linear expansion coefficient of $\mathrm{Cu}: \alpha_{\mathrm{Cu}}=1.63 \times 10^{-5} \mathrm{~m} /\left(\mathrm{m}^{\circ} \mathrm{C}\right)$. 


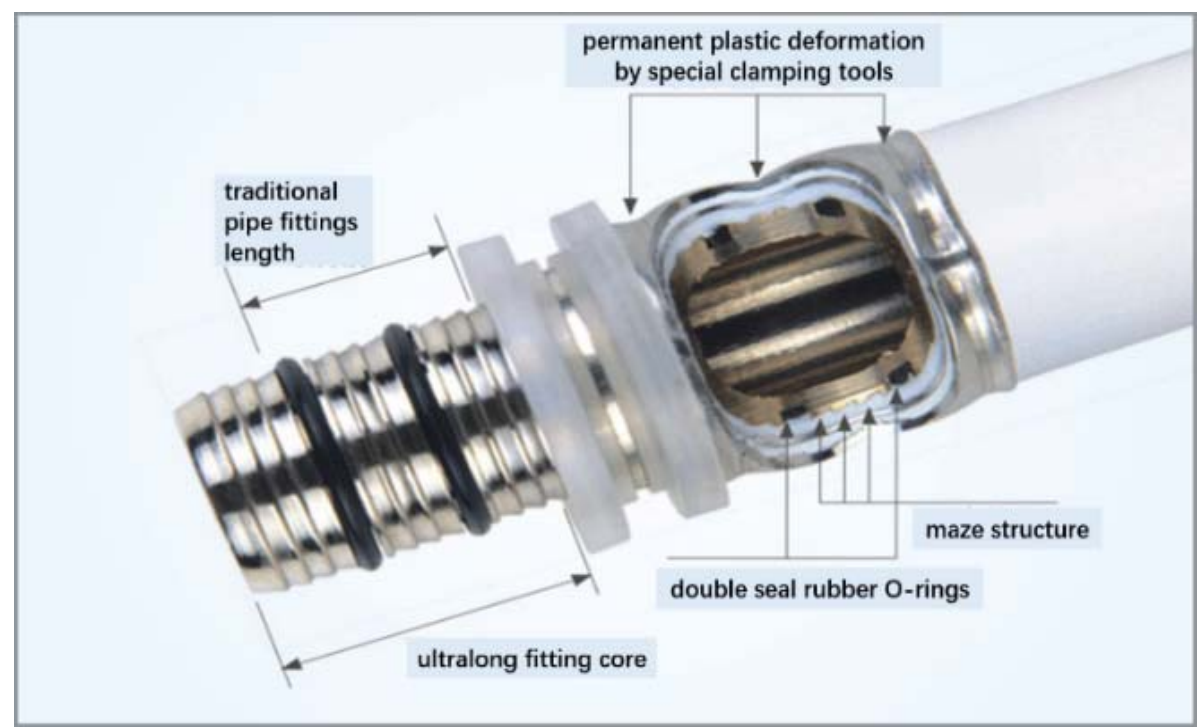

Fig. 4 Assembly diagram of press pipe fittings.

$$
\begin{aligned}
& \text { PE } \rho=0.95 \mathrm{~g} / \mathrm{cm}^{3}, \\
& \mathrm{G}_{1}=1.9 \times 3.1416 \times 0.2 \times 100 \times 0.95=113.4 \mathrm{~g} / \mathrm{m}= \\
& 0.1134 \mathrm{~kg} / \mathrm{m} .
\end{aligned}
$$

$$
\begin{aligned}
& \operatorname{AL} \rho=2.7 \mathrm{~g} / \mathrm{cm}^{3}, \\
& \mathrm{G}_{2}=1.9 \times 3.1416 \times 0.023 \times 100 \times 2.7=37.07 \mathrm{~g} / \mathrm{m} \\
= & 0.037 \mathrm{~kg} / \mathrm{m} .
\end{aligned}
$$

Tube weight per meter:

$$
\mathrm{G}=\mathrm{G}_{1}+\mathrm{G}_{2}=0.1134+0.0371=0.1505 \mathrm{~kg} / \mathrm{m} \text {. }
$$

When the length of the single riser along the wall is $L=100 \mathrm{~m}$, the weights are as follows:

Pipe weight $=0.1505 \times 100=15.05 \mathrm{~kg}$

PAP pipe bearing capacity and pull-out resistance:

Overlap welding standards (GB/T 18997.1) specified PE tensile strength should not be less than $15 \mathrm{MPa}$, plastic pipe bearing capacity $\mathrm{F}_{1}=1.9 \times$ $3.1416 \times 0.2 \times 150 \mathrm{~kg} / \mathrm{cm}^{2}=179 \mathrm{~kg}$;

Overlap welding standards (GB/T 18997.1) specified the aluminum strip tensile strength should not be less than $100 \mathrm{MPa}$, aluminum tube bearing capacity $\mathrm{F}_{2}=1.9 \times 3.1416 \times 0.023 \times 1,000 \mathrm{~kg} / \mathrm{cm}^{2}=$ $137 \mathrm{~kg}$.

The total load-bearing capacity $\mathrm{F}=\mathrm{F}_{1}+\mathrm{F}_{2}=179+$ $137=316 \mathrm{~kg}$, which is much larger than the weight of the pipe $15.05 \mathrm{~kg}$.

Therefore, in the absence of pipe brackets, PAP pipe itself can withstand the weight of 100 meters of pipe weight.

Resistance to pull-out force: the long-term pull-out force stipulated by the lap welding standard is $1,400 \mathrm{~N}$, i.e. $140 \mathrm{~kg}$, which is much larger than the weight of the pipe $15.05 \mathrm{~kg}$.

\subsection{Thermal Compensation of PAP Pipe}

Using 1620 tubes, the calculated length $L=100 \mathrm{~m}$, the linear expansion coefficient $\alpha$ PAP $=2.5 \times 10^{-5}$ $\mathrm{m} /\left(\mathrm{m} \cdot{ }^{\circ} \mathrm{C}\right)$, and the environmental temperature difference $\Delta T_{\max }=80^{\circ} \mathrm{C}$. Thermal elongation: $\Delta L=$ $2.5 \times 10^{-5} \mathrm{~m} /\left(\mathrm{m} \cdot{ }^{\circ} \mathrm{C}\right) \times 80{ }^{\circ} \mathrm{C} \times 100 \mathrm{~m}=0.20 \mathrm{~m}$, and the elongation was $0.20 \%$. The PAP pipe is a flexible pipe, and the elongation rate of the aluminum alloy in the middle layer is more than $20 \%$. The inner and outer PE layers are higher and can fully meet the change of the heat expansion amount. Therefore, we are not necessary to calculate the axial expansion compensation of pipes with $d_{n} \leq 32 \mathrm{~mm}$ caused by the temperature change [7].

\subsection{Anti-rodent Research}

In the southwestern region of China, there are many mice. If the gas meter box is not well sealed, they are easy to get into and bite the pipe, leading to the risk of gas leakage. So, it is essential to develop anti-rodent 
function on PAP pipe.

2.5.1 Effect of Different Capsaicin Additions for Same BATCH of Mice

Rat-biting PAP pipes with different capsaicin contents were prepared for rat-bite-proof test. Each set of tests used a tube of $800 \mathrm{~mm}$ and five rats. Each group of tests took 30 days. When the aluminum layer of the pipe was bitten through, the test was regarded as termination. The area measurement and termination judgment of the bite marks on the pipe surface were performed on $1,3,5,8,10,15,20$, and 30 days respectively. The test result is shown in Fig. 5.

From the data in the figure, it can be seen that on the 8 th day of the ordinary aluminum-plastic tube, the surface bite area has reached nearly $70 \%$, and on the 10th day, the tube is bitten and fails. It shows that ordinary PAP pipes are easily bitten by rats. As for PAP pipes with capsaicin, the bite phenomenon on the surface is improved. And with the increase of capsaicin content, the bite area of the pipe surface is gradually reduced, and the failure time caused by the bite is gradually increased. When the amount of capsaicin added was $1.0 \mathrm{wt} \%$, the condition of pipe bitten was stabilized. This shows that at this content of capsaicin, the anti-rodent performance can be effectively improved [8].

2.5.2 Effects of Different Capsaicin Contents in Different Batches of Rats

In the actual construction of PAP pipe, the vast majority of the tubes are placed in open spaces such as outdoors, so the tubes should not be bitten by the same batch of rats. Each mouse has different memories for their own stimulation. In order to avoid excessive memory and rat factors causing interference with the long-term rodent-proof test of the pipe, the same batch of pipe was used in the experiment. The test conditions were changed to replace a batch of rats every five days, and the PAP pipe was tested for uninterrupted biting. The test results are shown in Fig. 6.

In Fig. 5, due to the experimentally determined rats which only had a "memory effect" for five days, the phenomenon of pipe biting was more severe than the "memory effect" of thirty days. The overall tube was shortened by the bite failure time, and the bite area was increased. When the amount of capsaicin added

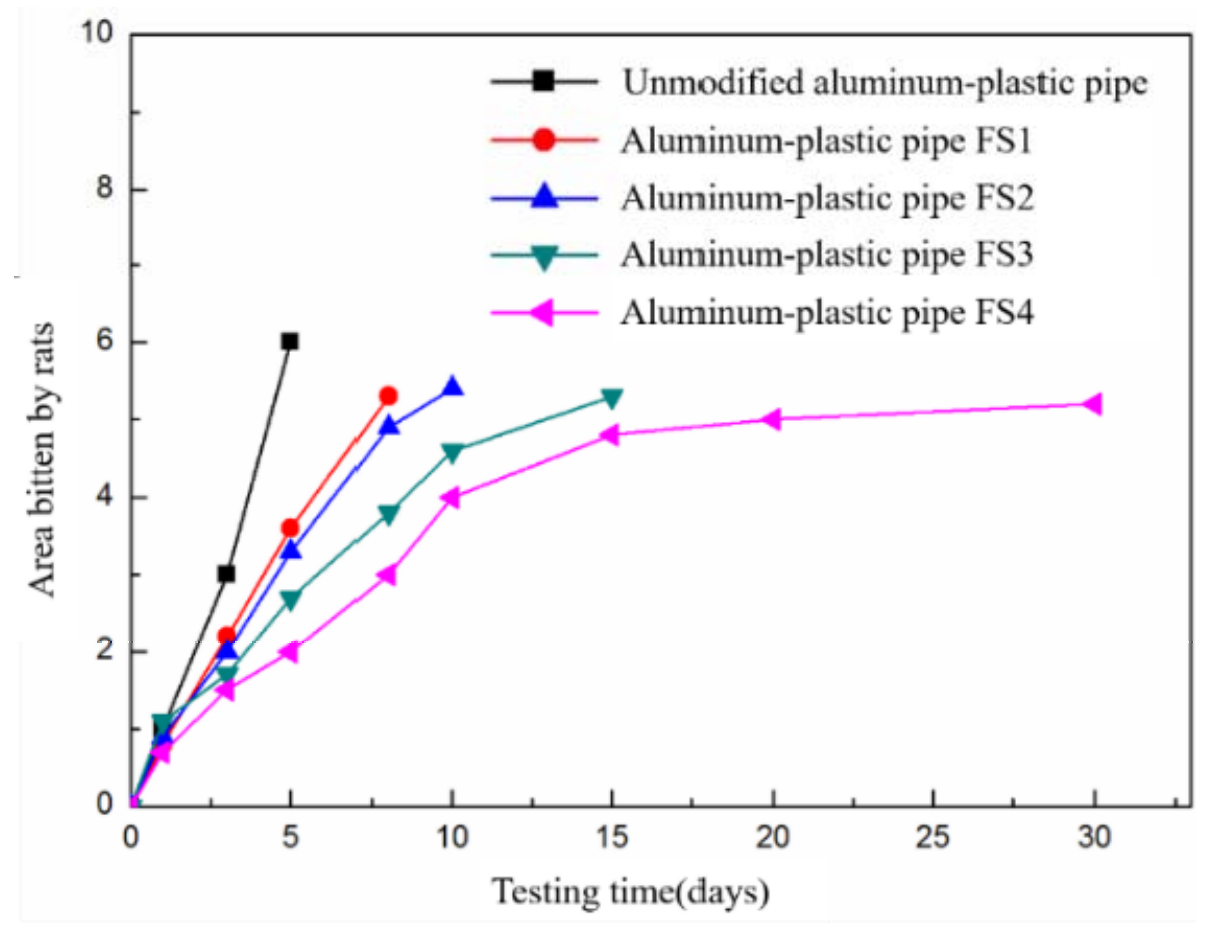

Fig. 5 Test on bite phenomenon of PAP pipes with different capsaicin content in the same group of rats. 


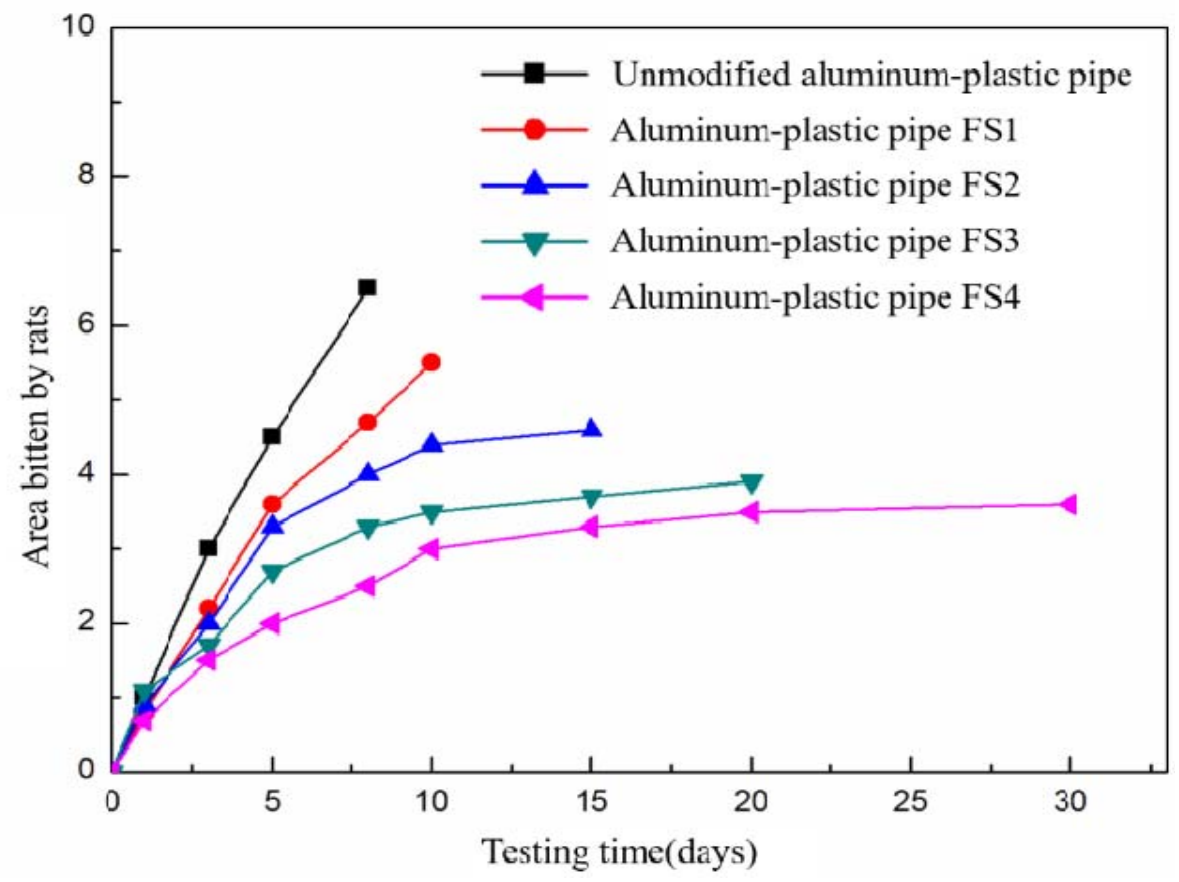

Fig. 6 Test of bite phenomenon of aluminum-plastic tube with different capsaicin content in different batch rats.

was $1.5 \mathrm{wt} \%$, the bite area on the surface of the pipe reached about $50 \%$. With this added amount, after the test on the fifteenth day of the rodent-proof aluminum-plastic tube, the surface bite area became stable, and at the end of the thirty-day test period, the pipe was not bitten. The results showed that for a rat population with unspecified and high fluidity, the addition of capsaicin at $1.5 \mathrm{wt} \%$ improved the rodent-proof performance of the aluminum-plastic composite tube. After rat bite test, when the additive amount of rat bite additive was $1.5 \mathrm{wt} \%$, the anti-rodent performance of the pipe was significantly improved.

\subsection{Outdoor Installation Specifications}

Combining the research in Sections 1.1 and 1.2, Rifeng edited the CECS 264 "Technical Specification for Polyethylene-Aluminum Composite Pipeline Engineering for Building Gas Supply" of the China Engineering Construction Association in 2009. The main contents of outdoor installation (application examples are shown in Fig. 8) are as follows:

2.6.1 Requirements for PAP Pipes in Casing

When the gas meter is installed outdoors and concentrated, and the PAP pipe is laid along the outdoor wall, the PVC casing or other effective protection measures shall be installed and the following provisions shall be complied with:

(1) Multiple sets of PAP pipes in the casing should be installed at one time;

(2) It is forbidden to install joints in PAP pipes in casings.

2.6.2 Requirements for Casing Installation

The Installation of (Hard Polyvinyl Chloride) Casing (schematic diagram demonstrated in Fig. 7) should meet the following requirements:

(1) The diameter of the casing shall meet the requirements for the crossing and bending radius of the PAP pipe, and the PAP pipe can not be forced into the casing;

(2) The upper end of the protective tube of the main riser shall have downwardly bent ventilation holes; the main transverse pipe casing shall be oriented to the gas distributor in the concentrated meter box, and the slope shall meet the following requirements: Natural gas, liquefied petroleum gas casing is not less than $1 \%$; Artificial gas casing is not less than $5 \%$; Casing should be firmly fixed; 


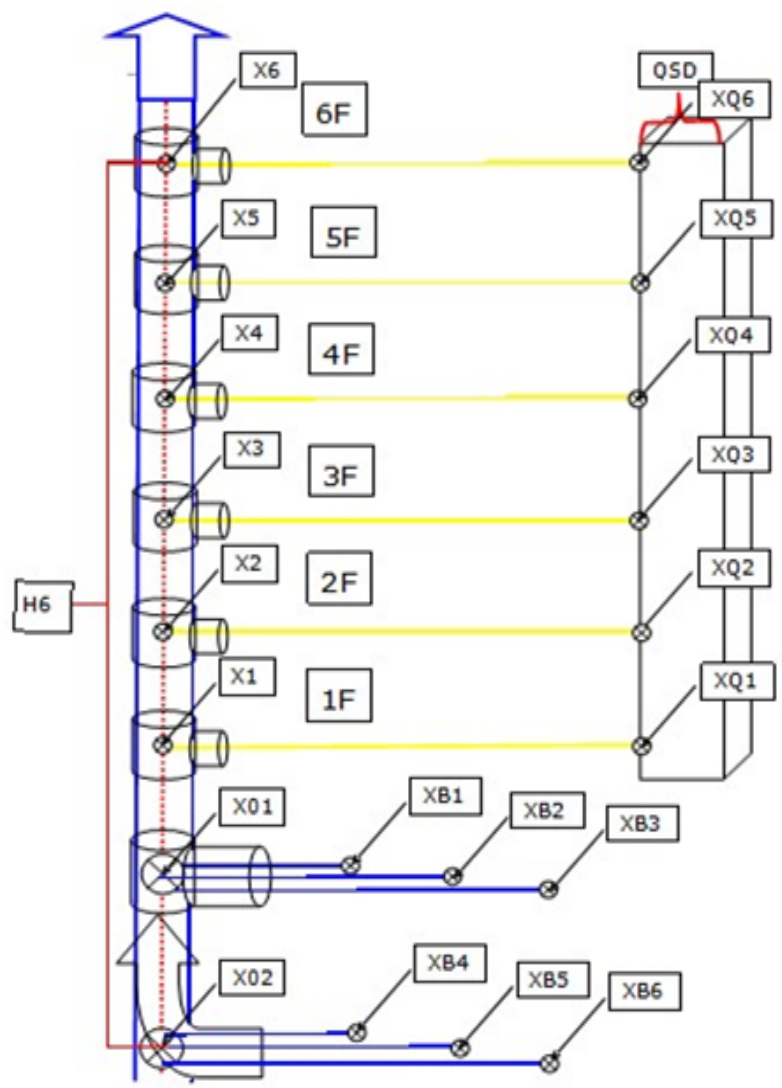

Fig. 7 Outdoor climbing wall installation (X1-6: $45^{\circ}$ oblique three links; XQ1-6: reserved hole; XB1-6: gas meter).
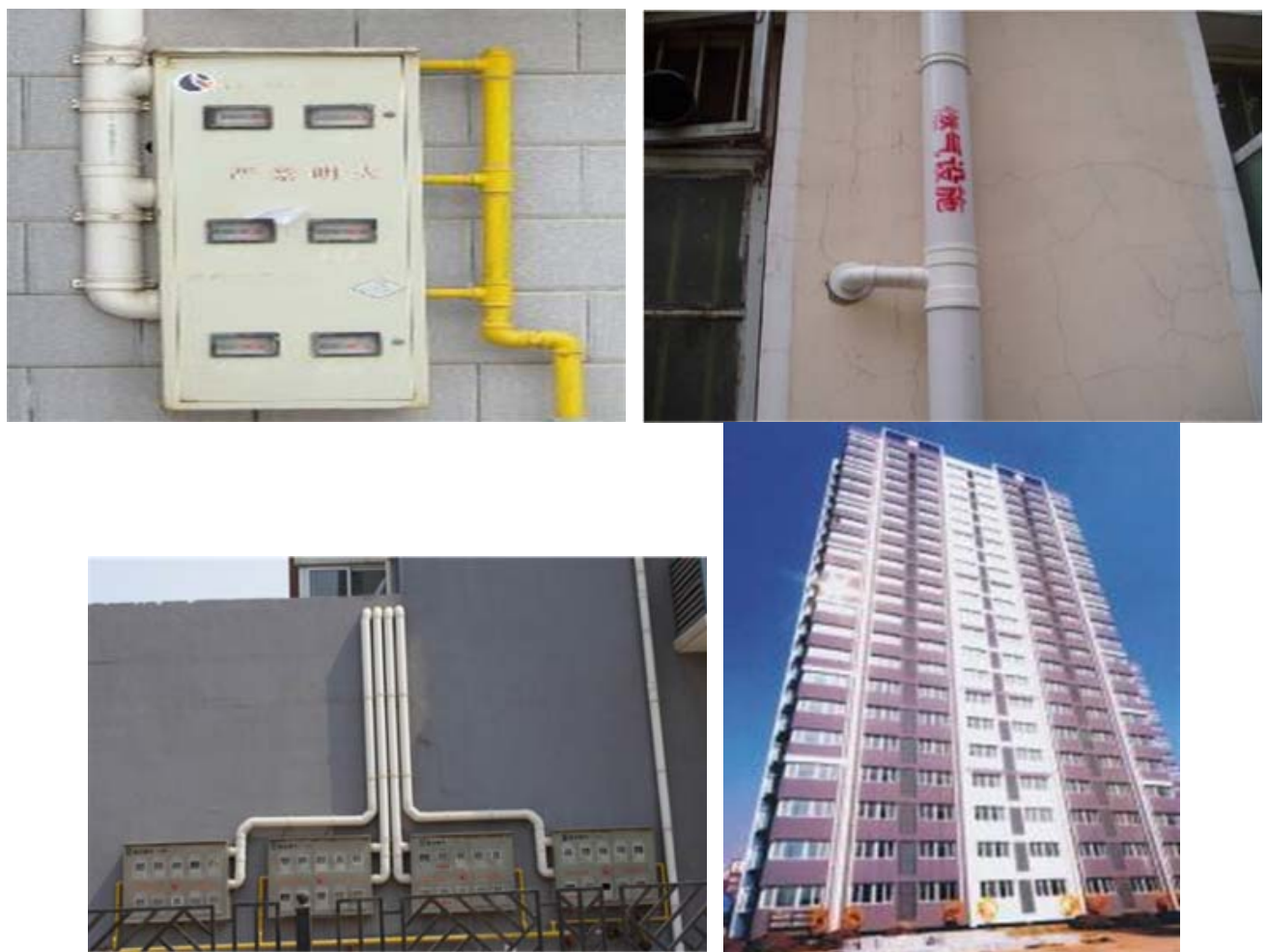

Fig. 8 Outdoor climbing wall installation example. 


\subsubsection{Requirements for Casing Surfaces}

The inner wall of the movable stent used for PVC casing shall be smooth, and there shall be micro-gap between the stent and the wall of the tube.

2.6.4 Requirements for Spacing of Fixing Brackets

The spacing of fixing brackets for hard PVC Casing shall meet the following requirements:

(1) When the nominal outside diameter is less than or equal to $50 \mathrm{~mm}$, it shall not be greater than $1.2 \mathrm{~m}$;

(2) When the nominal outside diameter is greater than or equal to $75 \mathrm{~mm}$, it shall not be greater than $2 \mathrm{~m}$.

\section{Conclusion}

(1) Compared with traditional galvanized steel pipe, PAP pipe combines the advantages of plastic and metal as a composite pipe, and has the advantages of corrosion resistance, long life, easy installation, and the application in gas will be more and more extensive.

(2) Through the testing and calculation of environmental temperature, reliability of connection and sealing, bending without rebound, stress bearing and heat compensation, the outdoor centralized wall-mounting method is adopted. The safety of the application of PAP pipe in PVC casing is fairly high.

(3) Preparation of rodent-proof additives through capsaicin, adding $1.5 \mathrm{wt} \%$ to the outer layer of the pipe, the performance of the pipe meets the requirements of the standard, and has a good anti-rodent effect.

\section{Acknowledgements}

Zhengzhou Gas Company, Chongqing Gas Company, Guangzhou Synthetic Materials Research Institute are gratefully acknowledged for experiment collaborations.

\section{References}

[1] 2009. CJJ94-2009 Code for Acceptance of Construction and Quality of City Indoor Gas Engineering.

[2] 2009. CECS 264-2009 Technical Specification for Polyethylene-Aluminum Composite Pipeline Engineering for Building Gas Supply. China Planning Press.

[3] 2003. GB/T 18997.1-2003 Aluminum-Plastic Composite Pressure Pipe Part 1: Aluminum Pipe Overlap Welding Type Aluminum Plastic Pipe. China Standard Press.

[4] Li, B. Q. 2004. "Aluminum-Plastic Composite Pipe and Fittings for Indoor Gas." In Proceedings of 2004 Conference of China City Gas Association Applied Professional Committee.

[5] Li, B. Q. 2008. "Mechanical Connection and Hot Melt Connection Technology of Aluminum-plastic Pipe.” In Proceedings of 2008 Tianjin Plastic Pipeline Promotion and Application Technology Forum.

[6] 2006. GB 50028-2006 Code for Design of City Gas Engineering. China Building Industry Press.

[7] Qin, X. M., Peng, X. Y., Li, B. Q., Wang, J., Zheng, C., Wang, H. J., and Liu, Y. 2015. Preparation and Performance Research of Antistatic Polyethylene Composites for Gas Pipes." Aging and Application of Synthetic Materials 44 (6): 12.

[8] Wang, J., Guan, Z. X., Qin, X. M., Peng, X. S., and LI, B. Q. 2005. "Research on Application of Capsaicin in Aluminum-Plastic Composite Pipes." Aging and Application of Synthetic Materials 32 (5): 59-62. 